Dept. of Poultry diseases.

Fac. Of Vet. Med. Assiut University.

Head of Dept. Prof. Dr. S. Mousa.

\title{
VIRAL HAEMORRHAGIC DISEASE OF RABBITS: COMPARATIVE STUDY BETWEEN THE IMMUNE RESPONSE OF LOCAL AND IMPORTED VACCINE \\ (With 2 Tables)
}
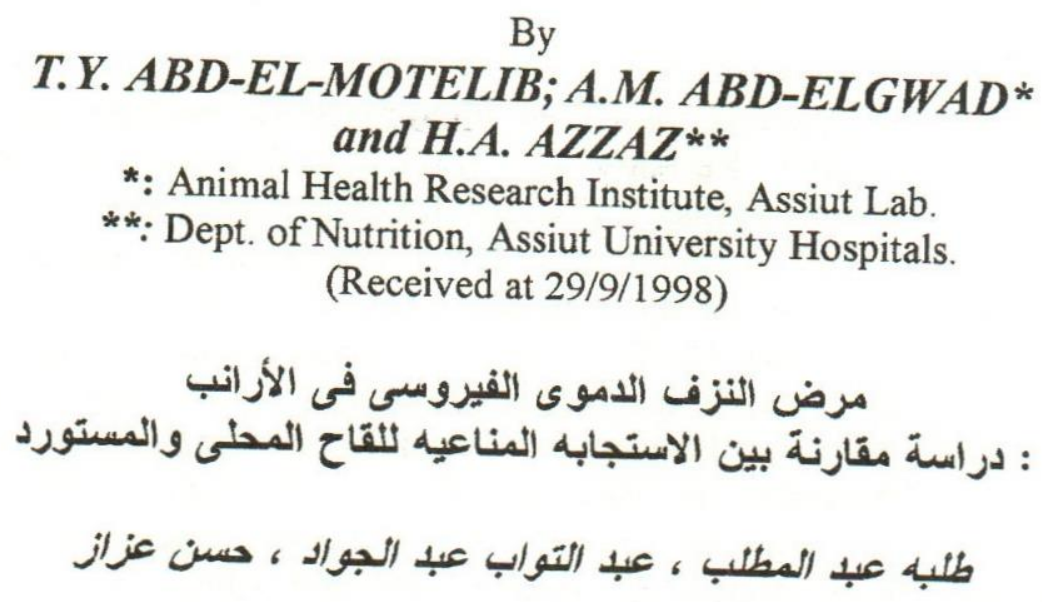

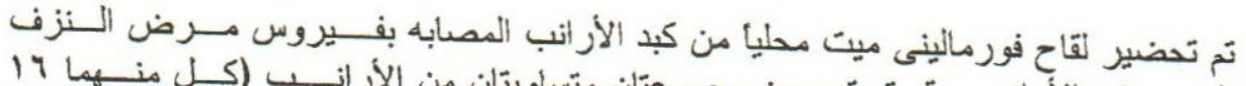

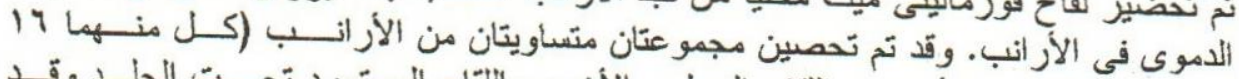

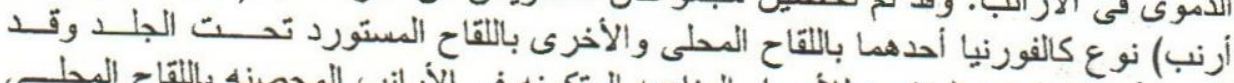

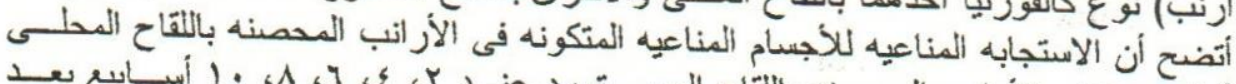

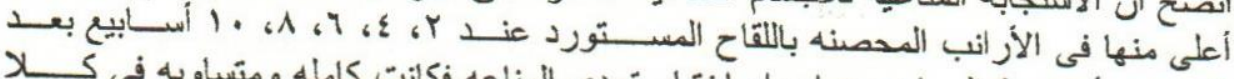

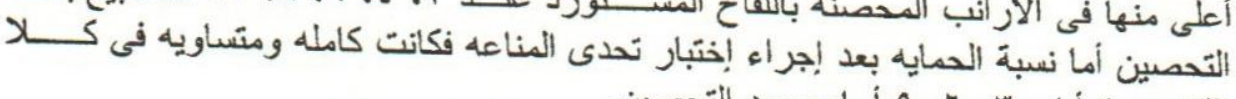

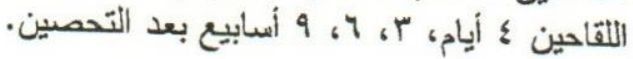

\section{SUMMARY}

Inactivated formalinized tissue vaccine was prepared locally from liver suspensions of rabbits infected with rabbit haemorrhagic disease virus. Thirty two california rabbits, 2 month old were inoculated subcutaneously with local and imported vaccines. (16 rabbits for each vaccine). Haemagglutination inhibiting antibodies were determined in both vaccinated groups $2,4,6,8$ and 10 weeks post vaccination and showed that rabbits vaccinated with local vaccine gave higher antibody 
titer than rabbits vaccinated with imported vaccine. Both an inactivated vaccine either locally prepared or imported gave full protection against challenge with rabbit haemorrhagic disease virus at 4 days, 3, 6 and 9 weeks after vaccination in comparison with $100 \%$ mortality of unvaccinated control rabbits.

\section{Key Words: Immune, Response of Local and Imported Rhvv}

\section{INTRODUCTION}

Nowadays rabbits has some advantages over other herbivorous and omnivores, together with their importance for meat production in developing countries. Recently one of the most fatal diseases affecting rabbits is viral haemorrhagic disease. It is highly fatal disease causing mortality up to $100 \%$ (Fioretti et al. 1991). The causative agent of rabbit haemorrhagic disease (RHD) was discovered and identified in 1984 in china (Liu et al. 1984). The First report of disease in Europe was in Italy (Marcato et al. 1988), Bulgaria (Belemezov et al. 1989). Austria (Kolbl et al. (1990), Belgium (Peeters et al. 1990). In U.K. (Fuller et al., 1993), in scotland (Patterson and Howie, 1995). In Egypt the disease firstly reported by Ghanem and Ismail (1991). Then salem and Ballal (1992), El-Zanaty (1994), Abdel-Aziz et al (1995) and Amina et al. (1996). Rabbit viral haemorrhagic disease affect more frequently adult rabbits and spread rapidly among susceptible flocks with high morbidity and mortality. Recently Jichuanyi et al. (1994) identified the virus isolated from infected suckling rabbits by immunofluorescence and PCR while HA testing could not always detect atypical RHDV infection. No treatment was effective so controlling depend on general preventive measures and vaccination. Inactivated tissue vaccine induce immunity 3 5 days after vaccination and can stop the spread of the disease, induction of rapid immunity coordinated by macrophages and $\mathrm{T}$ and $\mathrm{B}$ lymphocytes, while humoral immunity plays the main role in long term protection (Wei et al. 1987, Du et al. 1991, Huang. 1991, Haralambiev et al. (1991), Salem and El-Zanaty 1992 and Twigg et al. (1997). The purpose of this study was undertaken to compare the immune response generated following the vaccination with locally prepared and imported vaccines. 


\section{MÁTERIAL and METHODS}

Virus: The virus was previcusly isolated and identified from outbreaks of rabbits in Assiut province by Salem and El-Ballal (1992). Antigen Preparation:

The isolated virus was injected $1 \mathrm{ml}$ bacteria free sisspension of liver subcutaneously into 5 rabbits 2-month-old, within 48-96 hours of infection the rabbits died, livers were collected aseptically, then minced and bacteria free suspension was prepared.

\section{Inactivation for vaccine preparation:}

To inactivate the antigen 0.4 formalin was added to the liver suspension, then the treated suspension was left in the refrigerator for 48 hours. The adjuvant (mineral mixture and lanoline) from middle east company was added to the inactivated antigen in equal volume after autoclaving. The prepared formalinized inactivated vaccine contained $1 \mathrm{mg}$ of infective tissue (equivalent to 10.000 viral particles) per dose according to (Haralambiev et al 1991). follows:

Sterilily and safety tests for the vaccine were carried out as

\section{1- Sterility:}

\section{2- Safety:}

Subculture from the vaccine on bacteriological media.

Two healthy rabbits, 2- month-old were subcutaneously injected with $1 \mathrm{ml}$ of the vaccine and observed for deaths and symptoms for one week.

\section{Imported vaccine (cunical):}

Adjuvanted inactivated vaccine against rabbit viral haemorrhagic disease produced by Rhone Merieux.

Experimental animals: Forty 2-month old california rabbits were obtained from Assiut rabbitary farm with no history of VHD outbreaks and prove free from RHDV and antibodies as well as other bacterial and parasitic diseases. These animals were divided into three main groups.

Group I: Contain 16 animals, each animal inoculated with local vaccine $0.5 \mathrm{ml} /$ subcut.

Group II: Contain 16 animals, each animal inoculated with imported vaccine $0.5 \mathrm{ml} /$ subcut. 
Group III: Contain 8 animals were left as unvaccinated control. Challenge test:

At periods of 4 day, 3, 6 and 9 weeks from the beginning of the experiment, 2 animals from each of the three groups were challenged by $1 \mathrm{ml}$ of virus suspension from infected liver containing the virulent virus for vaccine evaluation. All challenged rabbits were kept under observation for 7 days post challenge. Clinical signs, post mortem and deaths were recorded on both dead and sacrified rabbits.

Haemagglutination inhibition (HI) test. Was performed after $\mathrm{Pu}$ et al. (1985). Blood from 8 animals of each of the vaccinated groups was tested at 2, 4, 6, 8 and 10 weeks post vaccination for $\mathrm{HI}$ antibodies to RHDV. chicken.

Erythrocytes: Citrated blood samples were collected from

Haemagglutination test (HA test): was detected using the method described by Kolbl et al. (1990).

\section{RESULTS}

No animals were distressed or died during vaccination as a result of vaccination with either local or imported vaccines.

The local prepared formalized inactivated vaccine proved to be sterile by no bacterial growth in the bacteriological media and safe by no deaths or clinical signs were observed after vaccination.

$\mathrm{HI}$ serum levels in all periods after vaccination are shown in table (1). The highiest $\mathrm{HI}$ antibodies were observed after 4 weeks after vaccination and continue till the end of experiment in local vaccine group but only for 8 weeks post vaccination in imported vaccine group. In all challenge periods at 4 days, 3,6 and 9 weeks post vaccination, no clinical signs or deaths were observed in both local and imported vaccine groups but all challenged unvaccinated control rabbits were died within 48-72 hours after challenge, the result shown in table (2). Depression, off food, incoordination before deaths were the prominent signs, noticed in the challenged unvaccinated group of rabbits. The post mortem lesions were paleness of liver, haemorrhages on lungs and congestion of spleen \& kidney in 3 cases. 
Table (1): illustrate mean HI titers in rabbits vaccinated with local and imported

\begin{tabular}{|c|c|c|c|c|c|c|c|c|}
\hline \multirow[t]{3}{*}{ Group } & \multirow{3}{*}{$\begin{array}{l}\text { Type of } \\
\text { vaccine }\end{array}$} & \multirow{3}{*}{$\begin{array}{l}\text { No.of } \\
\text { rabbits }\end{array}$} & \multirow{3}{*}{$\begin{array}{c}\text { Dose and } \\
\text { route of } \\
\text { vaccination }\end{array}$} & \multicolumn{5}{|c|}{ Mean HI titer } \\
\hline & & & & \multicolumn{5}{|c|}{ Weeks post vaccination } \\
\hline & & & & 2 & 4 & 6 & 8 & 10 \\
\hline 1- & $\begin{array}{l}\text { Local } \\
\text { vaccine }\end{array}$ & 8 & $0.5 \mathrm{ml}-\mathrm{S} / \mathrm{C}$ & $\begin{array}{l}1 / 256- \\
1 / 512 \\
\end{array}$ & $\begin{array}{l}1 / 512- \\
1 / 1024\end{array}$ & $\begin{array}{l}1 / 1024 \\
1 / 2048\end{array}$ & $\begin{array}{l}1 / 1024- \\
1 / 2048\end{array}$ & $\begin{array}{l}1 / 512- \\
1 / 2048\end{array}$ \\
\hline $2-$ & $\begin{array}{l}\text { Imported } \\
\text { vaccine }\end{array}$ & 8 & $0.5 \mathrm{ml}-\mathrm{S} / \mathrm{C}$ & $\begin{array}{l}1 / 128- \\
1 / 512\end{array}$ & $\begin{array}{l}1 / 256- \\
1 / 1024\end{array}$ & $\begin{array}{l}1 / 512- \\
1 / 1024\end{array}$ & $\begin{array}{l}1 / 512- \\
1 / 1024\end{array}$ & $\begin{array}{l}1 / 256- \\
1 / 512\end{array}$ \\
\hline
\end{tabular}

Table (2): illustrate protection percentage of challenge with RHDV at 4 days .3,6 and 9 weeks post vaccination with local and imported vaccines.

\begin{tabular}{|c|c|c|c|c|c|c|c|}
\hline Group & $\begin{array}{c}\text { Type of } \\
\text { vaccine }\end{array}$ & $\begin{array}{c}\text { Total } \\
\text { no. of } \\
\text { rabbits }\end{array}$ & $\begin{array}{c}\text { No. of animal } \\
\text { per challenge }\end{array}$ & Breed & Age & $\begin{array}{c}\text { Mortality } \\
\text { no. }\end{array}$ & $\begin{array}{c}\text { Protection } \\
\%\end{array}$ \\
\hline $1-$ & $\begin{array}{c}\text { Local } \\
\text { vaccine }\end{array}$ & 8 & 2 & California & 2 month & $0 / 800.0$ & $100 \%$ \\
\hline $2-$ & $\begin{array}{c}\text { Imported } \\
\text { vaccine }\end{array}$ & 8 & 2 & California & 2 month & $0 / 800.0$ & $100 \%$ \\
\hline $3-$ & $\begin{array}{c}\text { Non } \\
\text { vaccinated }\end{array}$ & 8 & 2 & California & 2 month & $8 / 8100.0$ & 00.0 \\
\hline
\end{tabular}

\section{DISCUSSION}

Viral haemorrhagic disease of rabbits is one of the greatest catastrophes facing rabbitaries during the last few years of twentieth century. Several outbreaks were reported in Egypt in different localities causing high mortalities in adult rabbits population in our areas, Salem and Ballal (1992) and Aly (1998). In this work immune response of formalinized locally prepared tissue vaccine and imported one were detected. Haemagglutination inhibiting antibodies were detected at 2, 4, 6,8 and 10 weeks postvaccination, reach top 6-10 weeks and 4-8 weeks post vaccination respectively then gradually declines (Smid et al. 1991). There were a higher $\mathrm{HI}$ titer in the immune response of local than imported vaccine.

Rabbits vaccinated with local or imported vaccines were fully protected against challenge with virulent strain of the virus 4 days post vaccination and the full protection continued to 9 weeks post vaccination, Our results nearly in accordance with Wei et al (1987), Haung (1991) and Haralambiev et al (1991) who mentioned that formalinized tissue vaccine can stop the spread of the disease in 3-4 days of vaccination. Finally we can be concluded that formalinized tissue locally prepared and imported vaccines can control and eradicate the 
disease in rabbits in the affected areas. We prefer the usage of locally prepared vaccine due to its high immunological response and its low cost in comparsion with the imported one.

\section{REFERENCES}

Abdel-Aziz, A.M.; Said, A.M.; Soliman, A.M. and Bayoumi, A.H. (1995):

Epidemiological studies on rabbit viral haemorrhagic disease. Beni Suef. Vet. Med. Res. 5(1) 166-181.

Aly, S.I. (1998): Some studies on rabbit viral haemorrhagic disease in upper Egypt. Thesis submitted to fac. Of Vet.Med. Assiut Univ. Amina, A.M.; Hadia, A.A.; Dawlate, A.S. and Than, A. (1996): Studies on rapid diagnostic methods for rabbit haemorrhagic viral disease (RHVD). Vet. Med. J. Giza. 44(3) 601-611.

Belemezov, P.; Petkov, A.; Mitov, B. and Peshev, R. (1989): Pathological features of viral haemorrhagic disase of rabbits. Veterinarna sbirka, 87 (10) 17-21.

Du, N.X., Xu, W.Y., Lui, S.J., Xu, F.N., Yu, Y.R.; Li, R.J. (1991): Studies on rabbit haemorrhagic disease. Scientia Agricultura sinica 24(1) $1-10$.

El-Zanaty, K. (1994): Some investigations on rabbit viral haemorrhagic disease in upper Egypt. Assiut. Vet. Med. J. 30 (60) 293-305.

Fioretti, A.; Menna, L.F.; Fiorilli, G. and Papparella, V. (1991): viral haemorrhagic disease of rabbits: results of epidemiological studies carried out in the Molise region of Italy. Revista di coniglicoltura, 28 (4) 37-42.

Fuller, H.E.; Chasey, D.; Lucas, M.H. and Gibbens, J.C. (1993): Rabbit haemorrhagic disease in the united kingdom. Vet. Rec. 133 (25/26) 611-613.

Ghanem, T.A. and Ismail, A. (1991): Occurrence of rabbit haemorrhagic disease in sharkia province. Egyptian-German Veterinary Medical Conference Nov. 12-15.

Haralambiev, H.; Peschiejski, P., Jotov, M.; Dimitrov. K.; Vasilev, V. and Petkov, P. (1991): Active immunization of rabbits against viral haemorrhgic disease. Tierarztliche umschau, 46 (3)155158.

Huang, H.B. (1991): Vaccination against and immune response to viral haemorrhagic disease of rabbits. A review of research in the people's republic of china. Revue scientifique et technique. Office international des epizooties. 10(2) 481-498. 
Ji chuanyi, Zhang Ying, Sun Zhifengi Du Nianxing. (1994): Experimental infection of young and suckling rabbits with rabbit haemorrhagic disease virus. Animal Husbandry and Veterinary Medicine 26 (5) 212-214.

Kolbl, S.; Settele, J. and schonbauer, M. (1990): First occurrence of infectious haemorrhagic disease of rabbits in Austria. Berliner und Munchener Tierarztliche wochenschrift 103 (8) 261-266.

Lui, S.J., Xue, H.P.; Pu, B.Q. and Oian, N.H. (1984): A new viral disease in rabbits. Animal Husbandry and veterinary Medicine. 16 (6): 253-255.

Marcato, P.S.; Benazzi, G.; Vecchi, G.; Salda, L. Della: Simoni, P.; Aiello, P. and Tumino, G. (1988): Infectious necrotic hepatitis of rabbits. Pathogenic profile of new haemorrhagic disease. Revista di coniglicoltura. 25 (9) 59-64.

Patterson, L.A.P. and Howie, F.E. (1995): Rabbit haemorrhagic disease in scotland. Vet. R. 137. 523.

Peeters, J.E.; Broes, A. and charlier, G. (1990): First observations of viral haemorrhagic disease of rabbits (RHD) in Belgium. Annales de Medicine Veterinaire. 134 (8) 567-571.

Pu, B.Q.; Qian, N.H. and Oui, S.J. (1985): HA and HI tests for the detection of antibody titers to so-called haemorrhagic pneumonia in rabbits. Chinese Journal of Vet. Med. 11: 16-17.

Salem, B. and El-Ballal, S.S. (1992): The occurrence of rabbit viral haemorrhagic disease (RVHD) in Egypt. Assiut Vet. Med. J. 27(53) 295-301.

Salem, B. and El-Zanaty, K. (1992): Tissue derived inactivated vaccine against rabbit viral haemorrhagic disease. Proc. $5^{\text {th }}$ sci. Cong.

Fac. Vet. Med. Assiut university Nov. 8-10 Egypt.

Smid, B.; Valicek, L.; Rodak, L.; Stepanek, J. and Jurak, E. (1991):

Rabbit haemorrhagic disease an investigation of some properties of the virus and evaluation of an inactivated vaccine. Vet. Microbiol. $26(1 / 2) 77-85$.

Twigg, L.E.; Wheeler, A.G.; Parkinson. J. (1997): Adverse reactions in wild, free-ranging European rabbits vaccinated against rabbit haemorrhagic Virus. Australian Vet. J. 75 (6) 448-449.

Wei, J.S.; Yu, N.S.; yang, Y.F.; Zhang, X.S.; Long, P.R and Shen, J.R. (1987): Investigation on a viral haemorrhagic disease in rabbits in Yunan province. Chinese Journal of Vet. Sci. and technology No. 8, 20-24. 
